\title{
Peningkatan Kemampuan Ketrampilan Administrasi Menggunakan Komputer Di Desa Cigugur Girang Parongpong Bandung Barat
}

\author{
Muhammad Ruslan Maulani \\ Politeknik Pos Indonesia
}

Dini Hamidin

Politeknik Pos Indonesia

\begin{abstract}
Based on Village Law No. 6 of 2014 that the village government has the responsibility to carry out the duties, rights, obligations and responsibilities of the village head in submitting the report and disseminating information on the implementation of Village Government in writing. The community service was carried out in the Cigugur Girang Parongpong Village, Bandung Regency. The implementation of this activity adopted the action research method and used the SKA model to determine the level of learning. The results of the implementation show that the training to increase the Administrative Skills Ability Using Computers in the Cigugur Girang Parongpong Village of West Bandung can improve both skills, knowledge and attitude in using Microsoft Word for the sake of completing the village administration work.
\end{abstract}

Keywords: Administration; Attitude; Knowledge; Skill

\begin{abstract}
Abstrak
Tulis Berdasarkan Undang-undang Desa No. 6 Tahun 2014 bahwa pemerintahan desa memiliki tanggung jawab untuk melaksanakan tugas, hak, kewajiban dan tanggung jawab kepala desa dalam menyampaikan laporan maupun menyerbarkan informasi penyelenggaraan Pemerintahan Desa secara tertulis. Pelaksanaan pengabdian kepada masyarakat ini dilaksanakan di Desa Cigugur Girang Parongpong Kabupaten Bandung. Pelaksanaan kegiatan ini mengadopsi metode action research dan menggunakan model SKA untuk mengetahui tingkat pembelajarannya. Hasil pelaksanaan menunjukkan bahwa pelatihan peningkatan peningkatan Kemampuan Ketrampilan Administrasi Menggunakan Komputer Di Desa Cigugur Girang Parongpong Bandung Barat dapat meningkatkan baik skill, knowledge maupun attitude dalam menggunakan Microsoft Word untuk kepentingan menyelesaikan pekerjaan administrasi Desa.
\end{abstract}

Kata kunci: Administrasi; Attitude; Knowledge; Skill

\section{Pendahuluan}

Desa Cigugur Girang Kecamatan Parongpong, Bandung Barat berdasarkan data BPS tahun 2017 memiliki 18 RW dan 69 RT dengan jumlah kepala keluarga 2.395 dengan tingkat kepadatan penduduk (16,58\%) ketiga terbesar dari 7 Desa di Kecamatan Parongpong. Penduduk pendatang Desa Cigugur Girang adalah $\pm 3 \%$ (keempat lebih rendah dibandingkan desa lainnya), dan memiliki tingkat kepindahan penduduk $\pm 13 \%$. Mata pencaharian di Desa Cigugur Girang di dominasi oleh pertanian $42 \%$ dan 21\% perdagangan dengan tingkat pendidikan di Desa Cigugur Girang 75\% adalah lulusan SD dan SMP (Badan Pusat Statistik, 2018).

Peningkatan kualitas layanan administrasi Desa mempunyai peranan penting dalam dalam peningkatan layanan di Kecamatan Parongpong, karena Desa merupakan layanan terdepan dalam melayani kebutuhan berbagai aktivitas layanan yang dibutuhkan oleh masyarakat. Berdasarkan undang-undang tentang Desa No. 6 Tahun 2014, Pasal 24 bahwa penyelenggaraan Pemerintahan Desa berdasarkan asas kepastian hukum, tertib penyelenggaraan pemerintahan, tertib kepentingan umum, keterbukaan, proporsionalitas, profesionalitas, akuntabilitas, efektivitas dan efisiensi, kearifan local, keberagaman, dan partisipatif. Selain itu 
juga pasal 26 (4h) menyatakan bahwa kepala desa wajib menyelenggarakan administrasi Pemerintahan Desa yang baik (Undang-Undang Republik Indonesia Nomor 6 Tahun 2014 Tentang Desa, 2014).

Untuk melaksanakan apa yang tercantum dalam undang-undang tersebut, yaitu menyelenggarakan administrasi Pemerintahan Desa yang baik, maka suatu hal yang penting sebuah Desa memiliki sumber daya manusia yang memiliki ketrampilan administrasi yang dapat mempercepat dan memberikan layanan administrasi yang optimal bagi seluruh warganya. Saat ini, tingkat pendidikan aparat desa selaku pengelola administrasi di Desa Cigugur Girang juga harus dapat meningkatkan kemampuan penguasaan teknologi, terkait dengan proses administrasi Desa. Berdasarkan hasil observasi dan wawancara di Desa Cigugur Girang, bahwa banyak perangkat desa yang masih belum menguasai aplikasi administrasi perkantoran seperti Microsoft office (Microsoft Word dan Microsoft Excel). Sedangkan aplikasi tersebut pada umumnya sudah menjadi satu keharusan untuk digunakan dalam pembuatan laporan ataupun pengolahan data dan administrasi Desa. Proses pembuatan laporan masih banyak dibantu oleh penyedia jasa pengetikan ataupun dengan menuliskannya tanpa menggunakan alat bantu aplikasi. Berdasarkan hal tersebut, maka dirasa perlu adanya kegiatan peningkatan ketrampilan administrasi perkantoran menggunakan komputer khususnya Microsoft Word bagi perangkat desa untuk dapat menyelesaikan berbagai persoalan administrasi.

\section{Metode Pelaksanaan}

Belajar adalah sebagai proses menjadi dirinya sendiri, maka kegiatan belajar harus melibatkan individu atau client dalam proses pemikiran apa yang mereka inginkan, mencari apa yang dapat dilakukan untuk memenuhi keinginan itu, menentukan tindakan apa yang harus dilakukan, dan merencanakan serta melakukan apa saja yang perlu dilakukan untuk mewujudkan keputusan itu. Orang dewasa sebagai siswa dalam kegiatan belajar tidak dapat diperlakukan seperti anak-anak didik biasa, orang dewasa yang tumbuh sebagai pribadi dan memiliki kematangan konsep diri bergerak menuju ke arah kemandirian atau pengarahan diri sendiri (Sunhaji, 2013). Sehingga untuk dapat meningkatkan kemampuan pengetahuan dan ketrampilan aparat desa dibutuhkan suatu metode yang tepat.

Pelaksananaan kegiatan ini dilakukan dengan mengadopsi metode penelitian tindakan (action research), dimana metode action research dilakukan untuk meningkatkan pemahaman dan praktik oleh praktisinya serta peningkatan situasi tempat pelaksanaan praktik. Fungsi penelitian tindakan sebagi alat untuk meningkatkan kualitas pelaksanaan kerja, seperti yang telah dilakukan oleh Kartowagiran pada penelitian action researchnya menggunakan siklus dari stinger (1996), yang terdiri dari: Look (mengumpulkan data atau informasi yang relevan), Think (menggali dan menganalisis apa yang terjadi di sini, dan bagaimana/mengapa bisa terjadi), dan Act (merencanakan tindakan dan mengimplementasikan, serta mengevaluasi) (Kartowagiran, 2005).

Keterlibatan orang dewasa dalam proses belajar sebelum dilakukan pelatihan harus di diagnosa terlebih dahulu terkait kebutuhan, tujuan, dan evaluasi hasil belajar serta implementasinya. Dengan mengadopsi action research, maka tahapan kegiatannya adalah sebagai berikut:

a. Melihat (Look) : digunakan untuk mengetahui kondisi awal, dengan mengumpulkan data dan informasi terkait jenis pekerjaan yang dilakukan oleh aparat desa.

b. Berpikir (Think) : melakukan analisis terhadap data dan informasi tersebut.

c. Bertindak (Act) : merencanakan metode pelatihan ketrampilan administrasi yang akan diberikan kepada aparat desa.

Berdasarkan penelitian yang dilakukan oleh Kandou dkk. bahwa knowledge management, skill, dan attitude memiliki pengaruh yang signifikan dan positif secara parsial terhadap 
terhadap kinerja karyawan (Kandou et al., 2016). Proses belajar orang dewasa berbeda dengan proses belajar anak-anak, dimana proses belajar orang dewasa merupakan proses transformasi, yaitu dalam bentuk mengubah, mempelajari kembali, memperbaharui, dan mengamati. Sehingga, proses yang tepat untuk pembelajaran orang dewasa dapat berupa pembelajaran mandiri, kerjasama kelompok, pemecahan masalah dan pembelajaran interaktif (Djumena, 2016). Jika dihubungkan dengan kegiatan peningkatan kemampuan ketrampilan administrasi aparat desa, maka untuk dapat meningkatkan kinerja aparat desa akan mengadopsi tiga pengaruh tersebut (knowledge, skill dan attitude) dalam metode pelatihan tersebut.

Berdasarkan pembahasan di atas, maka metode pelaksanaan kegiatan peningkatan kemampuan ketrampilan administrasi aparat desa adalah sebagai berikut:

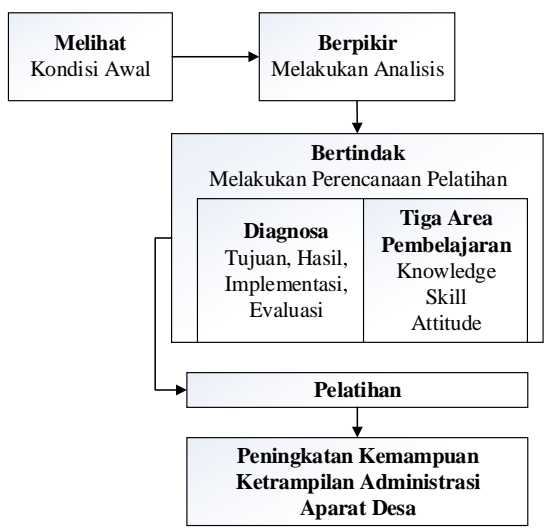

Gambar 1. Metode Pelaksanaan Kegiatam Pengabdian Kepada Masyarakat

\section{Hasil dan Pembahasan}

Berdasarkan metode penelitian, maka tahapan dari peningkatan kemampuan ketrampilan administrasi aparat desa terdiri dari Melihat, Berpikir dan Bertindak.

\subsection{Melihat Jenis Pekerjaan dan Kegiatan Aparat Desa}

Berdasarkan undang-undang tentang Desa No. 6 Tahun 2014 pasal 27, terkait dengan tugas, hak, kewajiban dan tanggung jawab kepala desa dalam menyampaikan laporan maupun menyerbarkan informasi penyelenggaraan Pemerintahan Desa secara tertulis, maka ketrampilan penggunaan aplikasi administrasi perkantoran menjadi hal yang harus dikuasai oleh aparat Desa.

\subsection{Berpikir Bagaimana Seharusnya Tingkat Kemampuan Aparat Desa}

Sumber daya manusia aparat Desa Cigugur Girang kurang lebih sebanyak 8 orang, dengan tingkat pendidikan SMA/SMK dan usia rata-rata berkisar 30 sampai dengan 35 tahun (usia dewasa) dengan jabatan sebagai berikut: Kepala BumDes, Kepala Karangtaruna, Bagian Keuangan, Sekretaris Desa, dan Staff Administrasi. Berdasarkan hasil observasi, sebagian besar mereka sering menggunakan jasa pengetikan atau menulis laporan tanpa menggunakan teknologi komputer. Penguasaan yang minim terkait keterampilan administrasi komputer aparat desa tersebut khususnya aplikasi perkantoran dalam hal ini adalah Microsoft office merupakan dasar dalam banyak pekerjaan aparat desa tersebut. Di lain pihak, mereka dituntut oleh kecamatan maupun stakeholder lainnya untuk dapat membuat proposal, pengumuman, pelaporan, surat undangan dan berbagai macam administrasi lainnya.

Salah satu aplikasi administrasi perkantoran adalah Microsoft office. Microsoft Office yang dapat membantu aktivitas pembuatan laporan adalah Microsoft Word. Sehingga pada kegiatan pengabdian kepada masyarakat ini, diprioritaskan pada peningkatan kemampuan 
penggunaan aplikasi Microsoft Word. Materi ketrampilan yang diberikan disesuaikan juga dengan aktivitas administrasi dan pelaporan yang banyak dilakukan oleh aparat Desa, adalah sebagai berikut:

Tabel 1. Aktivitas dan Kebutuhan Materi Microsoft Word

\begin{tabular}{cll}
\hline No. & Aktivitas & Materi yang Harus Dikuasai \\
\hline 1 & Materi pembuatan informasi dalam bentuk & Format Pengolah kata, gambar, tabel dan file \\
& pengumuman & Mail merge \\
2 & Pembuatan surat-menyurat/ undangan & Cover, Footer Header, page layout, references \\
3 & Pembuatan laporan & \\
\hline
\end{tabular}

\subsection{Bertindak Bagaimana Peningkatan Kemampuan Ketrampilan Administrasi dilakukan} bagi Aparat Desa

\section{a. Diagnosa}

Tahap ini digunakan untuk mendesain pelatihan yang akan dilakukan sampai dengan implementasi dan evaluasinya.

1) Tujuan , tujuan dari dilaksanakan kegiatan ini adalah untuk meningkatkan kemampuan aparat desa dalam penggunaan komputer untuk mengerjakan administrasi Desa seperti pembuatan pengumuman/informasi, Pelaporan, Surat Menyurat dan berbagai administrasi yang terkait dengan tanggung jawab dan pelayanan kepada masyarakat.

2) Hasil, Hasil dari pelatihan ini adalah meningkatnya kemampuan ketrampilan komputer khususnya Microsoft office (Microsoft Word), sehingga aparat desa dapat melakukan sendiri pengetikan pembuatan pengumuman, surat menyurat dan khususnya pelaporan sesuai dengan tanggung jawabnya.

3) Implementasi, pelaksanaan pelatihan ini menggabungkan 2 metode pembelajaran, yaitu:

\section{a) Metode Pembelajaran Langsung (Step-By-Step)}

Model pembelajaran yang menggunakan pendekatan mengajar yang dapat membatu aparat Desa dalam mempelajari keterampilan dasar dan memperoleh pengetahuan langkah demi langkah adalah model pengajaran langsung (direct Intruction). Sebuah model pengajaran bertujuan untuk membantu aparat desa dalam mempelajari keterampilan dasar dan pengetahuan yang dapat diajarkan langkah-demi-langkah.

Sehingga, model pembelajaran langsung ini merupakan sebuah model pembelajaran yang bersifat Teacher Centered (Berpusat pada Guru/Dosen/Pengajar), pada saat melakukan model ini pengajar harus mendemonstrasikan pengetahuan dan keterampilan yang akan dilatihkan selangkah demi selangkah.

\section{b) Metode Demonstrasi dan Contoh}

Metode demonstrasi dilakukan dengan menunjukkan dan merencanakan bagaimana suatu pekerjaan atau bagaimana sesuatu itu dikerjakan. Metode ini melibatkan penguraian dan memeragakan sesuatu melalui contoh-contoh. Metode ini sangat efektif, kaena lebih mudah menunjukkan kepada peserta cara mengerjakan suatu tugas, karena dikombinasikan dengan alat Bantu belajar seperti : gambar-gambar, teks materi, ceramah, diskusi. Pada kegiatan pelatihan Microsoft Word ini, metode tersebut digunakan bersamaan dengan metode pembelajaran langsung dimana peserta dapat saja menyela untuk berdiskusi mengenai berbagai permasalahan yang sering terjadi terkait pengolahan kata.

4) Evaluasi, untuk mengetahui tercapainya tujuan kegiatan ini, maka peserta diberikan pertanyaan-pertanyaan sebelum pelatihan tersebut dilaksanakan dan setelah pelatihan dilaksanakan dengan mengadopsi model tiga area pembelajaran (skill, knowledge, attitude). 


\section{b. Tiga Area Pembelajaran}

Tiga elemen pembelajaran sebagai pendukung, yaitu skill (ketrampilan), knowledge (pengetahuan) dan attitude (sikap) digunakan untuk mendukung pelaksanaan pelatihan dan evaluasi, sebagai berikut:

1) Skill, kemampuan penguasaan Microsoft Word terkait dengan kebutuhan materi pada Tabel 1. Sehingga elemen pertanyaan-pertanyaan terkait skill adalah sebagai berikut:

Tabel 2. Item-item yang ditanyakan pada Area Skill Pengoperasian Microsoft Word

\begin{tabular}{cll}
\hline No. & Materi yang Harus Dikuasai & Daftar Pertanyaan \\
\hline 1 & Format Pengolah kata, gambar, & - Dapat melakukan perubahan format pengolah kata \\
& tabel dan file & - Dapat menambahkan dan mengubah letak posisi \\
& & gambar \\
& & - Dapat membuat dan mengubah table \\
& & - Dapat menyimpan dan mengubah bentuk file \\
\hline $2 \quad$ Mail merge & - Dapat membuat tabel data untuk digunakan \\
& & sebagai alamat surat \\
& & - Dapat menggabungkan dua file \\
& & - Dapat menggunakan fasilitas mail-merge \\
\hline 3 & Cover, Footer Header, page & Dapat membuat cover \\
& layout, references & Dapat membuat dan menggunakan fasilitas header \\
& & dan footer \\
& & - Dapat membuat dan mengubah page layout dan \\
& & numbering \\
& & Dapat memanfaatkan fasilitas references untuk \\
& & membuat daftar gambar dan tabel \\
& &
\end{tabular}

2) Knowledge, mengadopsi apa yang dinyatakan Bakarman bahwa knowledge tacit merupakan pengetahuan yang dihasilkan dari pengalaman dan eksplisit merupakan pengetahuan yang diperoleh dari pendidikan secara akademis (Bakarman, 2011). Sehingga hal yang akan digali melalui knowledge ini adalah mengetahui apakah para aparat desa sebenarnya mengetahui cara mengoperasikan Microsoft Word melalui otodidak (trial and error) ataukah mengetahui dari membaca buku atau pernah mendapatkan ketrampilan tersebut namun mereka menganggap mereka tidak memiliki ketrampilan tersebut. Sehingga elemen pertanyaan-pertanyaan terkait knowledge adalah sebagai berikut:

Tabel 3. Item-item yang ditanyakan pada Area Knowledge Pengoperasian Microsoft Word

\begin{tabular}{|c|c|c|}
\hline No. & Jenis Knowledge & Daftar Pertanyaan \\
\hline 1 & Tacit Knowledge & $\begin{array}{l}\text { - Melakukan trial and error (coba-coba) saat harus } \\
\text { menyelesaikan pekerjaan administrasi } \\
\text { - Melakukan pencarian di internet atau menggunakan help atau } \\
\text { buku terkait penggunaan Microsoft Word pada saat harus } \\
\text { menyelesaikan pekerjaan }\end{array}$ \\
\hline 2 & Eksplisit Knowledge & $\begin{array}{l}\text { - Pernah mendapatkan pengetahuan cara mengoperasikan } \\
\text { Microsoft Word di sekolah } \\
\text { - Pernah mendapatkan pelatihan cara mengoperasikan } \\
\text { Microsoft Word }\end{array}$ \\
\hline
\end{tabular}

3) Attitude, mengambil apa yang dinyatakan oleh Lewis and Bonollo, bahwa attitude professional ada 5 kategori, yatu: tugas klarifikasi, pemecahan masalah, menerima tanggung jawab untuk hasilnya, ketrampilan interpersonal, mengatur tugas 
(Lewis \& Bonollo, 2002). Sehingga elemen pertanyaan-pertanyaan terkait attitude adalah sebagai berikut:

Tabel 4. Item-item yang ditanyakan pada Area Attitude Pengoperasian Microsoft Word

\begin{tabular}{|c|c|c|}
\hline No. & Kategori Attitude & Daftar Pertanyaan \\
\hline 1 & Tugas klarifikasi & $\begin{array}{l}\text { Menjelaskan cara mengoperasikan Microsoft Word kepada rekan } \\
\text { kerjanya }\end{array}$ \\
\hline 2 & Pemecahan Masalah & $\begin{array}{l}\text { Memberikan solusi jika rekan kerjanya ada yang kesulitan } \\
\text { mengoperasikan Microsoft Word }\end{array}$ \\
\hline 3 & $\begin{array}{l}\text { Menerima tanggung } \\
\text { jawab untuk hasilnya }\end{array}$ & $\begin{array}{l}\text { Mengerjakan pekerjaan administrasi sendiri, dengan melakukan } \\
\text { trial and error untuk mengerjakannya }\end{array}$ \\
\hline 4 & $\begin{array}{l}\text { Ketrampilan } \\
\text { interpersonal }\end{array}$ & $\begin{array}{l}\text { Bekerja sama membuat laporan dengan menggunakan Microsoft } \\
\text { Word dan menyatukannya dalam } 1 \text { file }\end{array}$ \\
\hline 5 & Mengatur Tugas & $\begin{array}{l}\text { Membuat laporan menggunakan Microsoft Word dan } \\
\text { menyelesaikannya tepat waktu }\end{array}$ \\
\hline
\end{tabular}

\subsection{Pelatihan}

Pelatihan Microsoft Word dilaksanakan di Desa Cigugur Girang dan dihadiri oleh 6 orang aparat desa. Sebelum dilaksanakan pelatihan Microsoft Word, diberikan terlebih dahulu daftar pertanyaan-pertanyaan yang sudah disusun pada tabel 2, tabel 3 dan tabel 4 . Setelah dilaksanakan pelatihan Microsoft Word diberikan kembali daftar pertanyaan tersebut. Berikut adalah gambar dari pelaksanaan pelatihan tersebut.
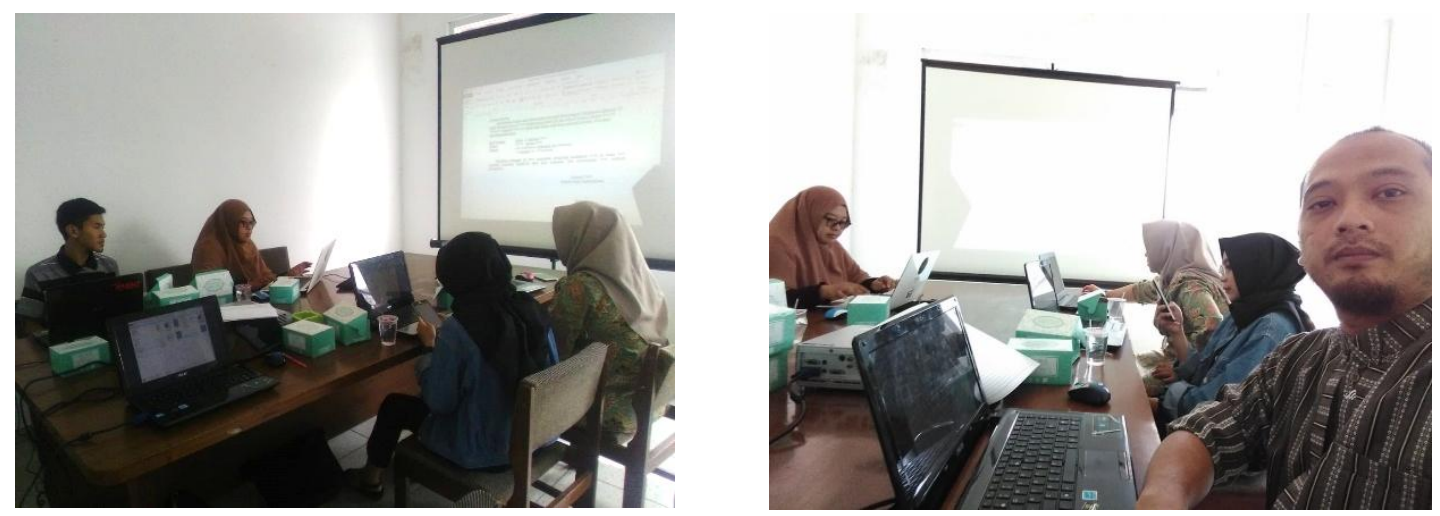

Gambar 2. Pelaksanaan Pelatihan Microsoft Word di Desa Cigugur Girang

Evaluasi berdasarkan hasil pelaksanaan kegiatan ini adalah dikelompokkan sebagai berikut:

a. Skill, pada umumnya mereka sudah dapat mengoperasikan Microsoft Word, meskipun masih banyak fasilitas-fasilitas di dalam Microsoft Word yang belum mereka gunakan untuk menyelesaikan pekerrjaan mereka, seperti membuat tabel data untuk digunakan sebagai alamat surat, menggabungkan dua file mail merge, membuat desain cover dan menggunakan fasilitas references untuk membuat daftar gambar dan tabel. Dengan adanya pelatihan ini, mereka dapat mengoptimalkan fasilitas-fasilitas yang ada di Microsoft Word untuk menyelesaikan pekerjaannya.

b. Knowledge, semua aparat desa melakukan trial and error (coba-coba) saat harus menyelesaikan pekerjaan administrasi. Sebagian lagi pernah mendapatkan pengetahuan cara mengoperasikan Microsoft Word saat di sekolah. Tetapi karena tidak fasih dalam mengoperasikan Microsoft Word dan tenggak waktu pekerjaan yang harus selesai, maka pekerjaan tersebut untuk pengoperasian yang kompleks dilakukan oleh pihak ketiga (jasa 
pengetikan). Namun setelah pelatihan Microsoft Word ini, mereka ingin mengerjakan sendiri pekerjaan administrasi tersebut.

Attitude, dengan adanya seorang aparat desa yang sedang menyelesaikan sekolah S1-nya, maka orang tersebut menjelaskan cara atau memberikan solusi jika ada permasalahan terkait mengoperasikan Microsoft Word kepada rekan kerjanya yang kesulitan dalam mengoperasikan Microsoft Word, meskipun karena kesibukan sekolahnya, tidak dapat dilakukan setiap waktu. Namun karena keterbatasan fasilitas yang mereka ketahui untuk mempermudah kerja mereka, maka belum pernah bekerja sama dalam membuat laporan dengan menggunakan Microsoft Word dan menyatukannya dalam 1 file. Pelatihan Microsoft yang sudah dilaksanakan dapat membuat mereka lebih percaya diri untuk dapat mengeksplorasi lagi fasilitas-fasilitas yang ada di Microsoft Word untuk menyelesaikan pekerjaan mereka tepat waktu.

\section{Kesimpulan}

Berdasarkan pemaparan di atas, maka dapat disimpulkan bahwa pelatihan peningkatan peningkatan Kemampuan Ketrampilan Administrasi Menggunakan Komputer Di Desa Cigugur Girang Parongpong Bandung Barat dapat meningkatkan baik skill, knowledge maupun attitude dalam menggunakan Microsoft Word untuk kepentingan menyelesaikan pekerjaan administrasi Desa.

\section{Ucapan Terima Kasih}

Terima kasih kepada Lembaga Penelitian dan Pengabdian Kepada Masyarakat (LPPM) Politeknik Pos Indonesia atas kepercayaannya dalam membantu terselenggaranya kegiatan peningkatan kemampuan ketrampilan administrasi Komputer. Terima kasih juga kepada Desa Cigugur Girang Kecamatan Parongpong Bandung Barat.

\section{Daftar Pustaka}

Badan Pusat Statistik. (2018). Kecamatan Parompong Dalam Angka 2017.

Bakarman, A. A. (2011). Attitude, Skill, and Knowledge: (Ask) a New Model for Design Education. Proceedings of the Canadian Engineering Education Association (CEEA). https://doi.org /10.24908/pceea.v0i0.3894

Djumena, I. (2016). Issn 2541-1462. 1(1), 11-18.

Kandou, Y. L., Lengkong, V. P. K., \& Sendow, G. (2016). Pengaruh Knowledge Management, Skill Dan Attitude Terhadap Kinerja Karyawan (Studi Pada Pt. Bank Sulutgo Kantor Pusat Di Manado). Jurnal Berkala Ilmiah Efisiensi, 16(1), 147-158.

Kartowagiran, B. (2005). Dasar-dasar penelitian tindakan. April 2005, 1-22.

Lewis, W. P., \& Bonollo, E. (2002). An analysis of professional skills in design: Implications for education and research. Design Studies, 23(4), 385-406. https://doi.org/10.1016/S0142 $-694 \mathrm{X}(02) 00003-0$

Undang-Undang Republik Indonesia Nomor 6 Tahun 2014 Tentang Desa, Pub. L. No. 6 (2014).

Sunhaji. (2013). Konsep Pendidikan Orang Dewasa. Jurnal Kependidikan, 1(1), 1-11. 


\section{Afiliasi:}

Muhammad Ruslan Maulani ${ }^{(\star)}$, Dini Hamidin

Program Studi Teknik Informatika, Politeknik Pos Indonesia, Bandung

Jl. Sari Asih No. 54, Bandung, 40151

E-mail : ruslanmaulani@poltekpos.ac.id( $\left.{ }^{(}\right)$,dinihamidin@poltekpos.ac.id 